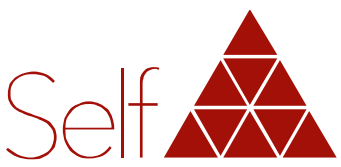

Revista do Instituto Junguiano de São Paulo

\title{
Quase-vida, o tsunami e a revolução da empatia
}

\section{Almost-life, the tsunami and the revolution of the empathy}
Casí-vida, el tsunami y la revolución de la empatía

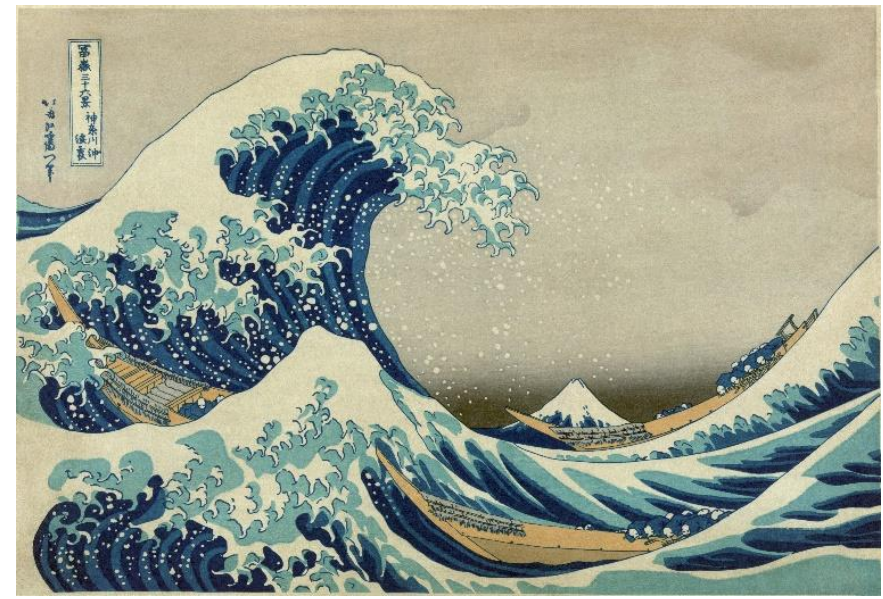

Figura. "A Grande Onda" de Kanagawa, por Katsushika Hokusai (17601849)

Fonte:

https://upload.wikimedia.org/wikipedia/commons/0/0d/Great_Wave_off_Kanagawa2.jpg

Uma imensa onda de partículas virais envolve a Terra. Se não global ainda, um tsunami com o potencial de atingir a totalidade do planeta. 
Já submergimos outras vezes em ondas imensas. Há cerca de 70 mil anos, um inverno vulcânico causado pela supererupção do vulcão Toba, onde hoje é Sumatra, quase causou a extinção da nossa espécie: a maioria (mais de 90\%) dos indivíduos que éramos então pereceu em um tsunami de gases tóxicos acompanhado de frio intenso e falta de alimento. Restaram menos de $10 \mathrm{mil}$ indivíduos humanos no planeta e todos nós descendemos destes Adões e Evas genéticos. Mas nós sobrevivemos.

E de algum modo perseveramos e prosperamos. Nessa época, ainda estávamos alguns milhares de anos distantes de começar a esculpir as nossas lindas Vênus paleolíticas, a pintar nas paredes de Chauvet, de Altamira e de Lascaux, ainda não havíamos manufaturado nossas primeiras flautas e nem domesticado nossos melhores amigos, os cães. $O$ pensamento de que todas essas maravilhosas construções humanas poderiam simplesmente não ter existido pode ser perturbador.

Um vírus não é considerado algo vivo. Há controvérsias no que venha a ser vida. A definição de vida é arbitrária, depende - por princípio - da existência de metabolismo capaz de produzir sua própria energia. A vida começa com uma célula. Um vírus é um bocado de material genético (RNA, DNA ou ambos) envolto por uma cápsula de proteína. Ele necessita de uma célula viva para se replicar, tomando-lhe a energia necessária para isso. Um vírus é um quaseser, uma coisa-partícula que, embora ínfima, tem a capacidade de infectar seres vivos. Muitas formas de vírus têm a capacidade de nos infectar e de nos causar doenças, direta ou indiretamente. E, usando-nos como vetores para o seu espalhamento, o novo coronavírus age como uma imensa onda que varre o mundo: e isto está acontecendo exatamente hoje. (E não há nada mais difícil e pretencioso do que tentar ser um observador da sua própria era.)

Nem todas as ondas que a mãe-natureza nos envia são destrutivas. Todos os anos uma imensa onda de quase 30 milhões de toneladas de areia cruza o oceano Atlântico vinda do Saara para fertilizar a Amazônia com milhares de toneladas de fósforo tão necessário e bem-vindo. A mãe-natureza é assim: ora cuidadora amorosa, ora cruel dispensadora da notícia que assusta. Assim somos também: por vezes cruéis e intolerantes, xenófobos e avessos ao outro, ao diferente e ao novo; outras vezes, cheios de compaixão e empatia, somos capazes de abraçar a Terra e estender a mão ao nosso desconhecido vizinho.

$\mathrm{Na}$ longa transição entre o pensamento antigo e o pensamento moderno surgiram, no período que a história chama de Idade Axial, religiões cujo cerne é a pregação da não-violência, do amor e da empatia: o taoísmo, o budismo e o hinduísmo moderno. No mesmo momento histórico surgiu na Grécia a filosofia: o amor pela verdade baseado no uso da razão humana e sua capacidade de arbítrio. A empatia certamente fez parte do que somos e da nossa história desde sempre - coisa arquetípica -, mas esses grandes movimentos religiosos e filosóficos - que encontraram no Ocidente o seu correspondente no cristianismo, poucos séculos adiante - mudaram o mundo. Apenas a partir de um novo paradigma no qual todo ser humano 
possui valor singular, sem equivalente ou possibilidade de equivalência, pudemos chegar à proposição de dignidade humana de Kant (1785/2013):

No reino dos fins tudo tem ou preço ou dignidade. Quando uma coisa tem preço, pode ser substituída por qualquer outra que the seja equivalente; o que, por outro lado, está acima de todo o preço, e, portanto, não permite equivalente, possui dignidade [tradução nossa] (Section 2, position 744).

Apenas a partir da empatia pudemos chegar à consciência dos direitos humanos.

É digna a nossa existência. É digno da nossa parte quando levamos o outro em consideração e aceitamos o confinamento momentâneo. $E$ assim não cuidamos apenas do outro tribal que habita o nosso horizonte conhecido, mas do outro desconhecido, de todos os outros.

Em uma época de polarizações raivosas e negações inconsequentes da ciência mundo afora e mesmo aqui no nosso amado Brasil, sobrevém uma condição da mãe-natureza que nos lança para dentro de nós mesmos, tornando-nos reflexivos; nos obriga a confiar na ciência, especialmente na ciência médica baseada em evidências; e nos abre as portas do sentimento da compaixão. Fluxo e refluxo. Para além do refluxo retrógrado de xenofobia e sectarismo nacionalista e populista, a evolução da vida e da civilização nos propõe um desafio: encontrar, na estrutura da ciência e na motivação da empatia, a esperança. Respeitemos e apoiemos a ciência, acolhamos o outro, e teremos porque ter esperança. Assim, sairemos do outro lado da grande onda uma humanidade diferente e melhor.

Ricardo Pires de SOUZA Presidente do Instituto Junguiano de São Paulo

\section{Referências}

Kant, I. (2013). Fundamental principles of the metaphysic of morals [Kindle]. New York, NY: Start Publishing. (Trabalho original publicado em 1785). 